\title{
Urgensi Evaluasi Untuk Pendidikan
}

\author{
Fitri Nur Rohmah \\ Sekolah Tinggi Agama Islam Al-Khairat Pamekasan \\ (fitrizanzan@yahoo.com)
}

\begin{abstract}
Abstrak
Salah satu kompetensi utama yang harus dimiliki oleh seorang guru adalah mampu melakukan evaluasi dengan baik. Ini penting dilakukan karena tujuan evaluasi selain untuk mengetahui tingkat keberhasilan siswa dan KBM, juga sangat penting digunakan untuk memilih strategi dan metode pembelajaran yang tepat dalam pembelajaran. Penerapan sistem evaluasi yang benar sangat dibutuhkan mengingat tidak semua guru bisa melakukannya. Secara teoritis mungkin mereka memahami evaluasi,tetapimasih banyak yang belum menerapkan langkah-langkah evaluasi yang benar. Oleh karena itu sangat diperlukan pengetahuan tentang langkah pelaksanaan evaluasi yang benar agar hasil evaluasi benar-benar menggambarkan kemampuandan keadaan siswa sehingga hasil evaluasi bisa digunakan sesuai dengan fungsi dan tujuan evalausi dalam pendidikan.
\end{abstract}

Kata kunci: evaluasi, tujuan pendidikan.

\begin{abstract}
:
One of the main competencies that a teacher must have is able to evaluate well. This is important to do because the purpose of evaluation beside to know the success degree of students and teaching and learning activity, is also very important to choose the appropriate strategies and methods in learning. The Implementation of a correct evaluation system is needed because not all teachers can do it. Scientifically and theorically they understood very well, but applying the correct evaluation steps is still very rare to conduct. Therefore it is necessary to have a knowledge of correct evaluation steps so that evaluation result will really describe the ability and state of student, hopefully the evaluation result can be used as a function and purpose of evalution in education.
\end{abstract}

Keywords: evaluation, educational goals. preface/introduction 


\section{Pendahuluan}

Mengetahui tingkat pencapaian siswa dalam proses belajar mengajar merupakan hal yang sangat penting dan harus dilakukan oleh seorang guru. Hal ini dikarenakan mengetahui kemampuan mereka bisa dijadikan dasar oleh guru untuk mengambil keputusan sehubungan dengan pembelajaran. Guru bisa melanjutkan pembahasan materi, mengulang materi, atau perlu mengembangkan materi pada pembahasan yang lebih luas berdasarkan pemahaman siswa. Oleh karena itu sudah selayaknya guru mampu melakukan kegiatan evaluasi dengan baik dan benar agar tujuan pembelajaran dapat dicapai maksimal.

Kenyataanya guru masih banyak mengalami kesulitan dalam melaksanakan kegiatan evaluasi. Mereka belum memahami betul langkah-langkah yang tepat yang harus diterapkan dalam melakukan evaluasi seperti dalam proses pembuatan soal yang sesuai dengan tujuan evaluasi. Biasanya mereka menyamakan semua jenis tes untuk semua jenis evaluasi dengan tujuan yang berbeda. Padahal seharusnya jenis soal bisa dibuat sedemikian rupa disesuaikan dengan tujuan evaluasi yang telah ditentukan. Selain itu guru masih kesulitan dalam menentukan tingkat kesukaran soal dan mengetahui tingkat validitas dan reliabilitas tes yang dibuat.

Dengan alasan tersebut maka sangat penting bagi guru untuk mengkaji ulang dan memahami konsep evaluasi dengan baik dengan harapan agar guru bisa memahami konsep evaluasi sehingga bisa menerapkannya dalam kegiatan pembelajaran. Hal-hal penting yang harus diketahui oleh guru antara lain: pengertian evaluasi, tujuan evaluasi, macam-macam evaluasi, instrumen evaluasi, validitas dan reliabilitas tes, dan langkah pengembangan instrumen evaluasi.

\section{Pengertian Evaluasi Pendidikan}

Evaluasi merupakan kegiatan yang dilakukan seorang guru yang sangat erat hubungannya dengan dua kegiatan yakni kegiatan mengukur dan menilai. Mengukur merupakan kegiatan membandingkan sesuatu dengan ukuran. Pengukuran bersifat kuantitatif. Menilai merupakan langkah mengambil keputusan terhadap sesuatu berdasarkan ukuran baik dan buruk. Penilaian bersifat kualitatif. Kedua kegiatan tersebut merupakan kegiatan evaluasi. ${ }^{1}$

${ }^{1}$ Suharsimi Arikunto, Dasar-dasar Evaluasi Pendidikan. Edisi 2. (Jakarta: Bumi Aksara, 2012)3. 
Hal ini sesuai dengan yang dikatakan oleh Scriven bahwa pengukuran adalah penetapan angka dengan cara yang sistematik untuk menyatakan keadaan individu. Keadaan individu ini bisa berupa kemampuan kognitif, afektif, atau psikomotor. Akhirakhir ini juga dikembangkan kemampuan emosi yang diasumsikan dapat menentukan kesuksesan seseorang dalam melaksanakan pekerjaan. ${ }^{2}$ Stufflebeam berpendapat bahwa pengukuran, penilaian, dan evaluasi merupakan hierarki. Pengukuran membandingkan hasil pengamatan dengan kriteria, penilaian menjelaskan dan menafsirkan hasil pengukuran, dan evaluasi adalah penetapan nilai atau implikasi suatu prilaku yang diukur. $^{3}$

Untuk menentukan hasil evaluasi tentu guru perlu melakukan serangkaian kegiatan yang pada prosesnya mencakup pengukuran dengan sifatnya yang kuantitatif dan penilaian yang bersifat kualitatif. Artinya guru tidak hanya mengadakan tes yang cenderung kuantitatif tetapi perlu menafsirkan hasil tes yang dilakukan dengan melihat sejauh mana perubahan sikap siswa sebagai efek dari kegiatan belajar yang telah diikuti oleh siswa. Menurut Ralp Tyler evaluasi merupakan sebuah proses pengumpulan data untuk menentukan sejauh mana, dalam hal apa, dan bagaimana tujuan pendidikan sudah tercapai. Jika belum, bagaimana yang belum dan apa sebabnya. Definisi yang lebih luas diungkapkan oleh Cronbach dan Stufflebeam dua ahli evaluasi bahwa proses evaluasi bukan sekedar mengukur sejauh mana tujuan tercapai, tetapi juga digunakan untuk membuat keputusan. ${ }^{4}$

Berdasarkan pendapat yang dikemukan para ahli tersebut dapat ditarik kesimpulan bahwa kegiatan evaluasi perlu dilakukan dengan beberapa tahap yaitu mengukur terlebih dahulu, kemudian menilai atau menafsirkan hasil pengukuran dan mengambil kesimpulan dari kedua proses tersebut. Dengan demikian evaluasi harus dilakukan dengan proses yang tidak hanya sekali jalan tetapi perlu melalui tahap-tahap atau prosedur yang diatur sedemikian rupa dengan rinci.

\footnotetext{
${ }^{2}$ Scriven, Madaus. The Methodology of Evaluation dalam Perspective of Curriculum Evaluation, (Chicago: Rand McNally and Company, 1967), 8

${ }^{3}$ Stufflebeam, D.L. 1973. Educational Evaluation and Decision Making. (Itasca Illionis: F.E. Peacock Publisher), 17

${ }^{4}$ Cronbach, L.E..Essential of Psychology Testing, (New York: Harper, 1970), 19
} 


\section{Evaluasi Pendidikan}

1. Bagi Guru

Bagi guru, evaluasi dapat mengetahui sejauhmana keberhasilan KBM. Dengan evaluasi dapat diketahui siswa-siswa mana yang memahami pelajaran dan siswa yang kurang memahami atau belum menguasai materi. Dengan mengetahui hasil belajar siswa, guru dapat memberikan perhatian pada siswa yang kurang pemahamannya. Hasil evaluasi juga bisa digunakan untuk mengetahui apakah materi yang diajarkan telah tepat bagi siswa atau tidak, sehingga bisa dijadikan pedoman pada pembelajaran yang akan datang. Guru juga bisa mengetahui apakah metode yang digunakan dalam mengajar sudah tepat atau belum.

\section{Bagi Siswa}

Hasil yang diperoleh siswa dalam evaluasi ada dua macam yaitu memuaskan atau tidak memuaskan. Hasil yang memuaskan akan menyenangkan dirinya sehingga dapat meningkatkan motivasi siswa untuk mencapainya di lain waktu. Sebaliknya, hasil yang tidak memuaskan dapat digunakan sebagai pelajaran agar berusaha untuk mendapatkan hasil yang lebih baik di waktu lain.

3. Bagi Sekolah

Dengan evaluasi, sekolah bisa menunjukkan kualitas pelayanannya terhadap siswa dalam pembelajaran guna mencapai kualitas pendidikan yang diinginkan sehingga sekolah mampu bersaing dengan sekolah lain dan pada akhirnya mendapat tempat yang layak di hati masyarakat. Kualitas sekolah dapat dari hasil belajar siswa. Hasil belajar siswa dapat dijadikan sebagai pedoman oleh sekolah untuk mengetahui kualitas pembelajaran yang berlangsung di sekolah. Hasil belajar merupakan cerminan dari kualitas suatu sekolah. Hasil evaluasi dari tahun ke tahun juga bisa digunakan sebagai pedoman apakah yang dilakukan sekolah sudah sesuai standar atau belum. ${ }^{5}$

\section{Macam dan Fungsi Evaluasi}

Para ahli membedakan macam-macam evaluasi ini ke dalam beberapa bentuk. Ada yang membedakan berdasar fungsinya, bentuknya, dan ada juga yang membedakan

${ }^{5}$ Suharsimi Arikunto, Dasar-dasar Evaluasi Pendidikan.... 14-16 
berdasarkan tujuannya. Evaluasi berdasarkan fungsinya, bisa berarti selektif, diagnostic, penempatan, dan berfungsi pengukur keberhasilan. ${ }^{6}$

Penilaian untuk fungsi selektif digunakan agar guru bias menyeleksi siswanya seperti menyeleksi siswa yang bias diterima, siswa yang naik atau tinggal kelas, siswa yang seharusnya mendapat beasiswa, atau siswa yang berhak lulus dan tidak, dan sebagainya. Penilaian berfungsi diagnostic digunakan untuk mencari kelemahankelemahan yang dialami siswa sehingga guru bisa mencari solusi untuk mengatasinya. Penilaian untuk fungsi penempatan biasanya digunakan ketika guru akan memilih siswa untuk ditempatkan pada kelompok tertentu. Hasil penilaian merupakan sumber informasi untuk mengelompokkan siswa yang mempunyai kemampuan sebanding. Penilaian berfungsi sebagai pengukur keberhasilan untuk mengetahui sejauhmana keberhasilan suatu program pembelajaran dalam kurun waktu tertentu.

\section{Instrumen Evaluasi}

Instrument evaluasi adalah alat evaluasi yang digunakan untuk mengetahui perubahan prilaku siswa. Instrumen evaluasi dapat berupa tes dan nontes. Tes adalah suatu alat atau prosedur yang sistematis dan objektif untuk memperoleh data atau keterangan yang diinginkan tentang seseorang, dengan cara yang tepat dan cepat. Tes merupakan suatu teknik atau cara yang digunakan dalam rangka melaksanakan kegiatan pengukuran yang didalamnya terdapat berbagai pertanyaan atau serangkaian tugas yang harus dijawab atau dikerjakan oleh peserta didik untuk mengukur aspek prilaku peserta didik. ${ }^{7}$ Test is any series of questions or exercises or other means of measuring the skill, knowledge, intelligence, capacities of aptitudes or an individual or group. ${ }^{8}$ Instrumen evaluasi non-tes digunakan untuk mengukurperubahan sikap dan pertumbuhan peserta didik dalam psikologi. Teknik ini dapat dilakukan dengan berbagai macam cara seperti: observasi, wawancara, skala sikap,dan kuesioner. Gurusebagai seorang evaluator dapat menggunakan hasil evaluasi instrument non-tes ini sebagai pertimbangan dan laporan pencapaian hasil belajar karena jika data yang dikumpulkan hanya menggunakan tes

\footnotetext{
${ }^{6}$ Suharsimi Arikunto, Dasar-dasar Evaluasi Pendidikan .......,. 18-19

${ }^{7}$ Zainal Arifin,Evaluasi Pembelajaran (prinsip teknik dan prosedur,(Bandung: PT. Remaja Rosdakarya, 2013), 118

${ }^{8}$ Ebel, R.L. Essential of Educational Measurement, Englewood Cliffs, .....,.86
} 
saja maka data yang dikumpulkan menjadi kurang lengkap dan tidak bermakna, bahkan dapat merugikan pihak-pihak tertentu.

\section{Validitas dan Reliabilitas Instrumen}

Hal paling penting dalam evaluasi adalah bahwa hasil proses evaluasi harus benar-benar menggambarkan keadaan atau kemampuan siswa yang dievaluasi. Hal inilah bagian tersulit yang harus dikuasai guru sebagai pelaku evaluasi (evaluator). Guru dituntut untuk memilih dan membuat instrument yang berkualitas sehingga bisa membedakan kemampuan siswa yang dievaluasi. Oleh karenanya ada syarat mutlak bahwa instrument yang digunakan untuk mengevaluasi harus memenuhi dua syarat mutlak yakni valid (shahih) dan reliable (handal).

Tes yang valid adalah tes yang benar-benar mengukur apa yang hendak diukur. A test is valid if it measures what it purpose to measure. It can be said that a test is valid if the test really measures what to be measured. ${ }^{9}$ Valid artinya instrument benarbenar mengukur apa yang hendak diukur secara tepat. Misalnya alat ukur pelajaran Ilmu Pengetahuan Sosial (IPS), maka alat ukur tersebut harus benar-benar dan hanya mengukur kemampuan peserta didik dalam pelajaran IPS, tidak boleh dicampuradukkan dengan pelajaran yang lain. Begitu juga jika hendak mengukur keefektifan metode, media, penampilan guru, dan komponen-komponen pembelajaran lainnya. Validitas instrument evaluasi dapat ditinjau dari beberapa segi antara lain validitas ramalan (predictive validity), validitas bandingan (concurrent validity), validitas isi (content validity), validitas konstruk (construct validity), dan lain-lain. ${ }^{10}$

Syarat yang kedua sebuah tes dikatakan baik apabila memenuhi syarat reliabilitas. Ilustrasi dari reliabilitas tes sebagai berikut.Seseorang yang mengukur panjang sebuah meja kayu dengan menggunakan meteran secara berulang-ulang baik dalam tenggang waktu yang singkat atau lama maka hasil ukur akan dapat dipastikan menunjukan hasil yang sama selama meja tersebut belum berubah. Dapat dikatakan bahwa meteran tersebut sebagai alat ukur reliabel, konsisten, dapat diandalkan, atau stabil. Dari ilustrasi tersebut dapat disimpulkan bahwa tes dikatakan reliable apabila sebuah tes diujikan berulang-ulang pada objek yang samadan memperoleh hasil yang sama atau konsisten, kalaupun ada kenaikan nilai itu karena mereka pernah mempunyai

${ }^{9}$ Cronbach, Essential of Psychology Testing, ...., 76

${ }^{10}$ Zainal Arifin, Evaluasi Pembelajaran ...,69 
pengalaman mengerjakan tes tersebut. Artinya kedudukan siswa dalam kelompok tersebut tidak berubah.

Untuk mengetahui tingkat reliabilitas tes biasanya dilakukan dengan mengetahui seberapa besar indek reliabilitas sebuah tes dengan melakukan penghitungan secara statistik. Harga koefisien reliabilitas secara pasti tidak dapat diketahui tetapi dapat diestimasi atau diperkirakan. Hal ini bisa dilakukan dengan berbagai cara antara lain: koefisien stabilitas, koefisien ekuivalen, dan koefisien konsistensi internal. ${ }^{11}$

\section{Langkah Pengembangan Instrumen Tes}

1. Menyusun spesifikasi tes

Langkah pertama ini berisi tentang uraian yang menunjukkan keseluruhan karakteristik yang dimiliki sebuah tes. Spesifikasi yang jelas akan mempermudah dalam menulis soal, dan siapa saja yang menulis soal akan menghasilkan tingkat kesulitan yang sama. Langkah ini mencakup kegiatan: menentukan tujuan tes, menyusun kisi-kisi tes, menentukan bentuk tes, dan menentukan panjang tes. ${ }^{12}$

Sebelum melakukan langkah yang lain dalam langkah pengembangan tes seorang pembuat tes harus menentukan tujuan tes tersebut. Dalam dunia pendidikan tes bisa mempunyai tujuan antara lain tes penempatan (penempatan), tes diagnostik, tes formatif, dan tes sumatif. Setelah tujuan tes ditentukan maka seorang pembuat tes bisa melakukan langkah yang selanjutnya karena telah mengetahui dan menentukan tujuan tes yang akan dibuatnya.

Kisi-kisi merupakan tabel matrik yang berisi spesifikasi soal-soal yang akan dibuat. Kisi-kisi merupakan acuan bagi penulis soal, sehingga siapapun yang menulis soal akan menghasilkan soal yang isi dan tingkat kesulitannya relatif sama. Bentuk tes objektif bisa berupa tes pilihan ganda, benar salah, menjodohkan, dan uraian objektif. Selain itu ada juga tes non objektif yang biasanya digunakan dalam ilmu-ilmu social. Pemilihan bentuk tes yang tepat tergantung pada tujuan tes, jumlah peserta, alokasi waktu, cakupan materi, dan karakteristik mata pelajaran yang diujikan.

2. Menulis soal tes

\footnotetext{
${ }^{11}$ Zainal Arifin, Evaluasi Pembelajaran....259

${ }^{12}$ Djemari Mardapi. Penyusunan Evaluasi Hasil Belajar. (Universitas Negeri Yogyakarta. Diktat Kuliah, 2003) Tidak diterbitkan 45
} 
Setelah tujuan, panjang tes, dan kisi-kisi tes ditentukan langkah kedua adalah menulis tes. Seorang guru bisa memulai menulis tes yang telah ditentukan tersebut. Bentuk dan panjang tes bisa berdasarkan tes yang pernah diberikan pada siswa atau bisa diambil dari bank soal yang ada.

3. Menelaah soal tes

Kegiatan menelaah soal perlu dilakukan untuk memperbaiki soal jika masih ditemukan kekurangan atau kesalahan. Kegiatan ini lebih baik dilakukan oleh orang lain atau oleh sejumlah orang yang terdiri dari para ahli yang kompeten. Harapannya akan dihasilkan tes yang berkualitas dan sesuai dengan tujuan tes.

4. Melakukan ujicoba tes

Sebelum dilaksanakan tes yang sebenarnya, perlu dilakukan uji coba terlebih dahulu untuk memperbaiki kualitas tes. Uji coba digunakan sebagai sarana untuk memperoleh data empiric tentang tingkat kebaikan soal yang telah dibuat sehingga diperoleh data mengenai: validitas, reliabilitas, tingkat kesukaran, pola jawaban, efektifitas pengecoh, daya beda, dan lain-lain.

5. Menganalisis butir soal

Telah dijelaskan bahwa dari uji coba yang dilakukan akan diperoleh informasi penting tentang kualitas soal yang disusun. Oleh karena itu hasil uji coba perlu ditelaah kembali tiap butir soal seperti butir soal tersebut valid atau gugur, susunan bahasanya, tingkat kesukaran, daya pembeda, dan efektifitas pengecoh.

6. Memperbaiki tes

Setelah dilaksanakan uji coba tes dan ditelaah maka langkah selanjutnya adalah memperbaiki tes. Langkah ini biasanya dilaukan atas butir soal yaitu dengan memperbaiki masing-masing butir soal yang ternyata masih belumbaik. Ada kemungkinan beberapa butir soal yang sudah baik harus direvisi dan ada beberapa yang lain mungkin harus dibuang karena tidak memenuhi standar kualitas yang diharapkan.

7. Merakit tes

Setelah semua butir soal dianalisis dan diperbaiki, langkah selanjutnya adalah merakit butir-butir soal tersebut menjadi satu kesatua tes. Butir tes 
tersebut perlu disusun secara hati-hati menjadi satu kesatuan soal yang terpadu. Dalam merakit soal, hal-hal yang menyangkut validitas soal seperti nomor urut, bentuk soal, lay out perlu diperhatikan. Hal ini penting karena walaupun butirbutir soal sudah baik tetapi penyusunannya sembarangan dapat menyebabkan soal tersebut menjadi tidak baik.

8. Melaksanakan tes

Pelaksanaan tes merupakan kegiatan inti dimana soal yang telah dirakit diberikan kepada testee untuk diselesaikan sesuai waktu yang ditentukan. Pelaksanaan tes perlu pemantauan tes tetapi diharapkan pengawasan tersebut tidak mengganggu pelaksanaan tes itu sendiri. Peserta tes tidak boleh terganggu dengan kehadiran atau aktifitas pengawas tes karena hal tersebut akan berakibat pada tidak akuratnya hasil tes. Artinya pelaksanaan tes harus didesain sedemikian rupa agar berjalan dengan seobjektif mungkin.

9. Menafsirkan hasil tes

Hasil tes menghasilkan data kuantitatif yang berupa skor. Skor ini kemudian ditafsirkan menjadi nilai, yaitu rendah, menengah, atau tinggi. Tinggi rendahnya nilai ditentukan oleh acuan yang digunakan yaitui acuan norma atau kriteria. Nilai merupakan alat yang berguna untuk memotivasi siswa dalam belajar dan guru dalam mengajar. Dengan mengetahui nilai pencapaian belajar siswa dapat menyusun rencana perbaikan bisa juga reward atas jerih payahnya belajar sehingga menjadikan semangat untuk mencapaianya.

\section{Penutup}

Nilai merupakan informasi keberhasilan guru dalam mengajar. Faktor keberhasilan guru dalam mengajar memang banyak tetapi inti dari semuanya adalah penguasaan bahan ajar, keterampilan memilih dan menggunakan metode, keterampilan dalam memilih dan menggunakan media, dan cara melakukan penilaian termasuk tes yang digunakan. Oleh karena itu, pencapaian belajar atau prestasi belajar siswa merupakan fungsi dari siswa sebagai peserta didik dan guru sebagai pendidik, yaitu keberhasilan siswa dalam belajar dan keberhasilan guru dalam mengajar.Karena tingkat urgensi yang tinggi dari nilai inilah maka penyelenggaraan evaluasi sebagai media untuk memperoleh nilai ini diharapkan dapat dilaksanakan dengan benar dan objektif. 
Dengan sistem evaluasi yang baik maka akan diperoleh nilai yang bisa menggambarkan pencapaian siswa dengan sebenarnya. Sebaliknya pelaksanaan evaluasi yang kurang baik akan menghasilkan nilai yang tidak sesuai dengan perubahan prilaku siswa baik secara kemampuan maupun sikap. Hasil evaluasi selain digunakan untuk megisi laporan hasil belajar di buku raport, juga dapat dijadikan feedback bagi guru untuk melakukan refleksi pelaksanaan pembelajaran. Dengan demikian setiap saat guru dapat meningkatkan kinerjanya sehingga secara bertahap tapi pasti mutu pendidikan dapat ditingkatkan. 


\section{Daftar Pustaka}

Cronbach, L.E. 1963.Course Improvement through Evaluation, dalam Educational Evaluation: Theory and Practice (ed. Worthen, B.R dan Sanders, J.R.) Belmonth: Wardworth Publishing. Co.

Cronbach, L.E. 1970.Essential of Psychology Testing, New York: Harper.

Djemari Mardapi. 2003. Penyusunan Evaluasi Hasil Belajar. Universitas Negeri Yogyakarta. Diktat Kuliah: Tidak diterbitkan.

Ebel, R.L. 1972. Essential of Educational Measurement, Englewood Cliffs, New Jersey: Prentice-Hall.

Mulyadi. 2010. Evaluasi Pendidikan, Pengembangan Model Evaluasi Pendidikan Agama di Sekolah. Malang: UIN-MALIKI Press.

Scriven, Madaus. 1967. The Methodology of Evaluation dalam Perspective of Curriculum Evaluation. AERA I. (ed. Tyler, R.,et.al.). Chicago: Rand McNally and Company.

Stufflebeam, D.L. 1973. Educational Evaluation and Decision Making. Itasca Illionis: F.E. Peacock Publisher.

Suharsimi Arikunto, 2012. Dasar-dasar Evaluasi Pendidikan. Edisi 2. Jakarta: Bumi Aksara.

Zainal Arifin, 2013.Evaluasi Pembelajaran (prinsip teknik dan prosedur). Bandung: PT. Remaja Rosdakarya. 